\title{
The Solitary and Hatred within Social Media
}

\author{
Yánez Balarezo Samuel ${ }^{1}$ \\ Martínez Segovia Mayra ${ }^{1}$ \\ Derling José Mendoza Velazco ${ }^{2}$ \\ Lucano Alomoto Santiago ${ }^{1}$ \\ Sánchez Calderón Hugo Iván ${ }^{1}$ \\ Barros Bravo Renato Mauricio ${ }^{1}$ \\ ${ }^{1}$ Universidad UTE, Quito, Ecuador \\ ${ }^{2}$ Universidad Nacional de Educación UNAE, Azogues, Ecuador
}

Doi: 10.36941/ajis-2019-0006

\section{Abstract}

The Technology nowadays has a fundamental role when it comes to the changes made by humanity, which they have experimented throughout its history. The technology which covers both communication and information allows emotions, attitudes and values to be shown. These are implied due to them being generated in the network, developing forms of participation and the interaction between those who have a share common interest such as ideas, information, knowledge and entertainment. This research article provides a quick summary of the theoretical analysis of the "Martha" and "Diana" cases which occurred in Ecuador. The methodology applied was a mixed type with a sequential explanatory design (Dexplis). The analyzed material was collected, through the use of a software called Pandora Network Traffic Analyzer and by having a semi-structured interview which applied to two journalists and two University teachers in the social communication. The publications which are made by the social media and the data which is obtained by the key informants of the study, were verified by checking how the public opinion is influenced by the way in which the information is handled and exposed. The human actions migrate back to the network, where a confrontation between opponents and supporters is reflected. Furthermore, Network communication encourages citizens to discuss the controversial issues that bring down the real events, exalting solidarity and hatred of foreign immigrants residing Ecuador.

Keywords: Social networks; Information and communication technologies; Ecuadorian society; attitudes; emotional intelligence; symbolic interaction

\section{Introduction}

The influence of Information and Communication Technologies (ICTs) in all areas of society, has resulted in what is called cyberculture, which are "cultural transformations linked to the introduction of digital technologies in contemporary societies and, in particular, in those of the so-called Third World, through complex relationships of techno-social frameworks, in three areas, namely: the exercise of power, collective social action and aesthetic experience. "(Rueda, 2008, p.8). The development of multimedia and the rise of digital technology have displaced traditional tools such as printed material, audio and video recordings, messaging and telephone calls. The analogue 
material has become obsolete and has forced the transformation of libraries, newspapers, magazines, radio and television stations into digital formats, thus becoming in transmedial instruments, which have caused the dissemination of knowledge. For Cuartas (2017), "digital humanities" are not a transition from the human condition that abandons tradition and seeks without guidance the virtual, but the generation of shared knowledge that is built by social interaction and that increases reality and experience (Ebrahim \& Atteraya, 2019).

Society uses communication to converge, inform and share opinions on public and private aspects, but also to generate human ties. The media have seen the need to join the Social Media, since providing information is not enough now they must offer meeting and socialization points, as their consumers seek to interact, share ideas, entertain, to show interest to content and projects. The possibility of generating content from news information, gives people the ability to guide the opinion, and gives the possibility of generating networks that share it, and these in turn can exalt values such as solidarity or boost hate, and which can also end in off-line actions, acts that leave the networks to the physical world, there is a kind of continuity of virtual and face-to-face relationships that maintain and project political actions on decision-making centers or within, with interventions in the street, in places and, in general, in the urban environment (Muñoz, 2016).

\subsection{Social Network}

Since its creation, social networks, such as SixDegrees, Hi5, Facebook, MySpace, Linkedin, Instagram, Twitter and others, have captivated millions of people worldwide. According to the blog Management Information (2018), 88.90\% of Ecuadorians use the internet, $92 \%$ of these use social networks, and $88.90 \%$ of them are on Facebook. Social networks allow to gather and make visible contacts, actions, ideas, opinions, etc. This makes it possible to establish connections with people you could never meet. For Schwarz (2011) and Gladilina (2019), we distance ourselves from faceto-face communication with phone calls, now we distance ourselves from this by entering a textbased one. Social networks play an important role in the development of explanatory narratives, by increasing sociability, being a space to form and share ideas and opinions, an instrument that could foster a digital activism, which is understood as citizen empowerment that seeks social change.

\subsection{The Social and emotional intelligence.}

For Yermentaeyeva, Aurenova, Uaidullakyzy, Ayapbergenova \& Muldabekova (2013), social intelligence establishes an important margin in education, when referred to as an individual ability, to perceive information. Wechsler (1940), in his studies of emotional intelligence indicates "the difference he established between" intellectual elements "and" non-intellectual elements "was in the affective, personal and social factors, pointing out the need to consider the existence of these last ones. The full development of the intellectual elements in individuals, favors their ability to face situations, considering that their emotional act is based on the cognitive assessment of personal circumstances.

For Mayer and Salovey (1997), emotional intelligence is defined as: The ability to perceive, value and express emotions accurately, the ability to access and / or generate feelings that facilitate thinking; the ability to understand emotions and emotional knowledge and the ability to regulate emotions resulting in emotional and intellectual growth. Emotional intelligence in relation to the media is punctuated as the ability to take control and have an understanding of emotions and feelings, own and others (Mendoza, Gomez \& Gomez, 2018).

\subsection{Symbolic Interactionism}

Symbolic interactionism as a behavioral component of the interpretive paradigm relates the universal, psychological and sociological aspects in the human being, its theoretical principles are established by Blumer (1969), by enumerating that:

- Thinking ability is modeled by social interaction

- People are able to modify or alter the meanings and symbols they use in action and 
interaction based on their interpretation of the situation. (p. 271). Emotions widen the ability to solve various problems. The media serve as symbols, where subjects value various alternative actions before choosing one of them, reducing the possibility of making costly mistakes.

\section{Design and Method}

\subsection{Objective:}

Generate an analysis on how social networks can exalt solidarity and hatred in the Ecuadorian society in the "Martha" and "Diana" cases.

\subsection{Method:}

Under the objective set, the methodology developed was of a mixed nature through a sequential explanatory design (DEXPLIS), described by Hernández, Fernández and Baptista (2017) as a set of systematic, empirical and critical research processes and involve the collection and the analysis of quantitative and qualitative data. For the collection of data in the quantitative phase, a statistical monitoring was used in social networks, through the Pandora Network Traffic Analyzer system (current version). Monitoring systems are very useful tools not only to repair problems in a short time, but also to prevent failures, detect threats, and make correct decisions regarding the dissemination of information on the network; according to Ledesma \& Coya (2012) and Mendoza, Abrigo, Romero, Cueva \& Cejas, (2019). Based on the information obtained, a series of questions were designed in semi-structured interviews. Which were directed to 6 key informants of the investigation : 2 local journalist broadcasters, 2 university teachers of social communication and 2 students. These informants were selected in an intentional homogeneous non-probabilistic manner (Mendoza, 2018). During the transcription of their testimonies, they were codified sequentially, starting from Informant number 1 (Inf.1) to the sixth informant (Inf.6).

\section{Field Work and Data Analysis}

\subsection{Quantitative phase}

In order to obtain representative data on the "Martha" and "Diana" cases, the researchers applied the monitoring of social networks on news, opinions and criticisms during a period of 3 months (from January 21, 2019 until the day March 30, 2019). Data were selected for their highest percentage and analyzed descriptively.

\subsection{Qualitative phase}

The numerical results, frequencies and percentages in the previous phase, provided qualitative data on the most promoter media that spread the news about the "Martha" and "Diana" cases in the city of Quito. Also, the most frequent and related opinions were analyzed through data triangulation. These opinions were outlined, to be addressed to two participating Journalists and two University Professors. Therefore, the two university professors have a professional and academic view on the subject. Expressing their opinions and versions of opinions on how information should or should not be disseminated in ICTs.

\section{Results}

Over time, complaints about acts of gender violence in Latin America have increased significantly. On this concept is important to know and emphasize is a serious violation of human rights. For this reason, is important to carry out some research about this social problem, which is the responsibility of the entire society. For this reason, the analysis was carried out on the treatment of 
information in social networks on the cases of violence raised in January 2019, the Cases such as the: "Martha" and "Diana". Moreover, the monitoring in the social network during the first quarter of the year 2019, that is, in the months of January, February and March, has allowed us to decree through the data provided, the great impact on citizenship on issues related to gender violence. Since, when monitoring this social network, is indisputable that thousands of people react, reproduce and share the news that is published through various digital media.

\subsection{Quantitative results}

In the Martha case, the statistical results show during the beginning of publication a value of $60 \%$ popularity in the media, also in knowledge and opinions among citizens, about a collective violation perpetrated against a woman in Quito. The data reflect that in the month of February the percentage of information disseminated decreases up to $22 \%$, then an important detail is displayed, where sequentially it reduces up to $18 \%$ of publications in the month of March (view Table 1). When monitoring social networks about Diana's case, it can be seen that the largest number of publications on this event were raised during the month of January with $71 \%$ and March $21 \%$, with 71 publications being January with the highest interest which offers citizens (Table 1). The results indicate a non-sequential impact on frequency. The reason for descriptive nature is due to social changes or emotional reactions, where the Diana case is due to the death of a pregnant woman of Ecuadorian citizenship, carried out by a man of foreign nationality of immigrant status.

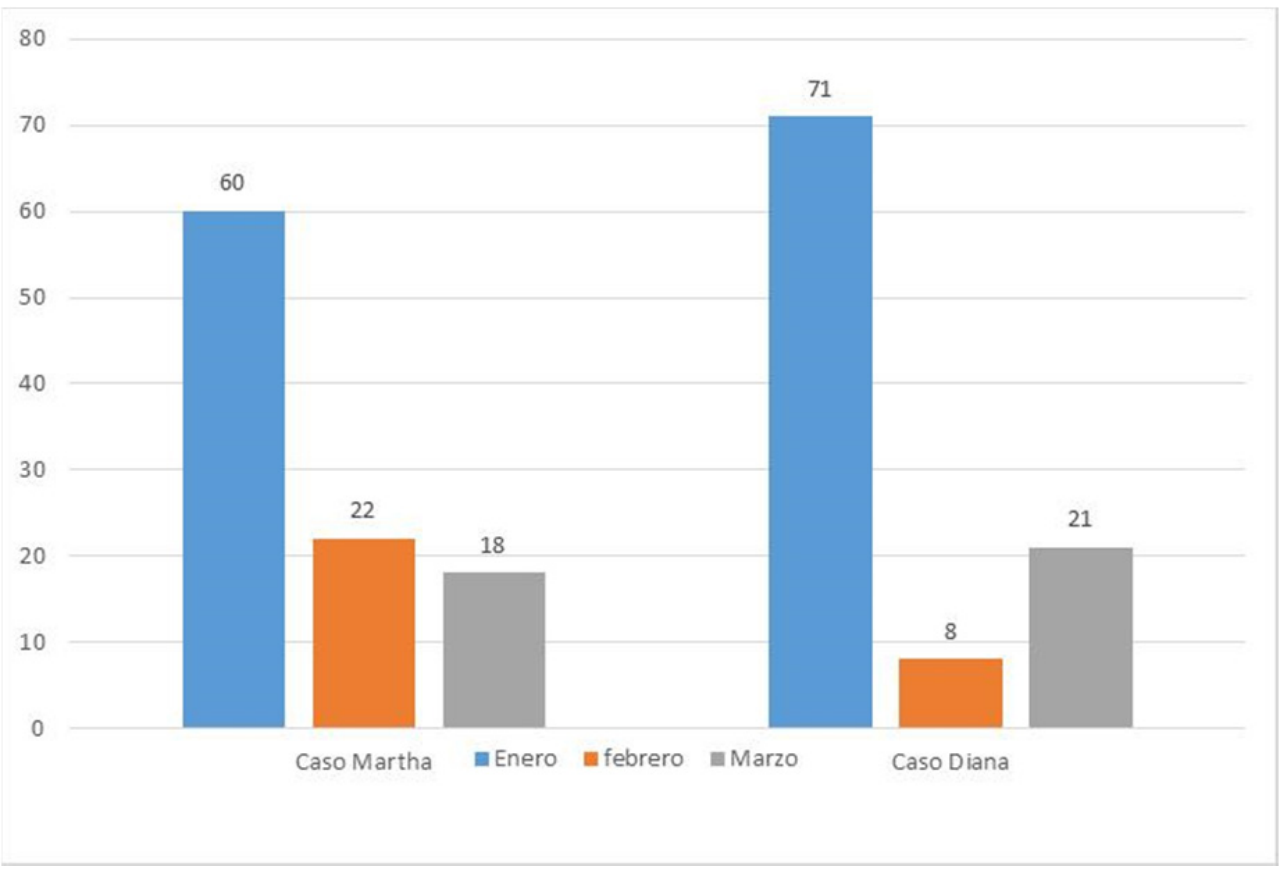

Table 1. Months of greater publication on the Martha and Diana cases.

It can be detected in the Diana case, that the percentage of frequency decreases in the month of February to an average limit of $8 \%$, but the acts widespread in the city of Ibarra, by social entities or people who are against violence gender, increased significantly, by the amount of opinions and publications during the month of March, generating rejection or hatred towards the foreigner's residence in Ecuador. In addition, the treatment that some media gave to this case was verified, which generated the outrage of the citizens for the violence in which was carried out. Within the 
media analyzed, the one that provided the most coverage to this fact of gender violence was "EI Comercio" that published 38 news items, followed by the "Universe" that referred to this issue 10 times. Next, the percentage distribution in which the number of occasions in which these media referred to the problem of gender violence occurred in the Diana case is shown in Table 2.

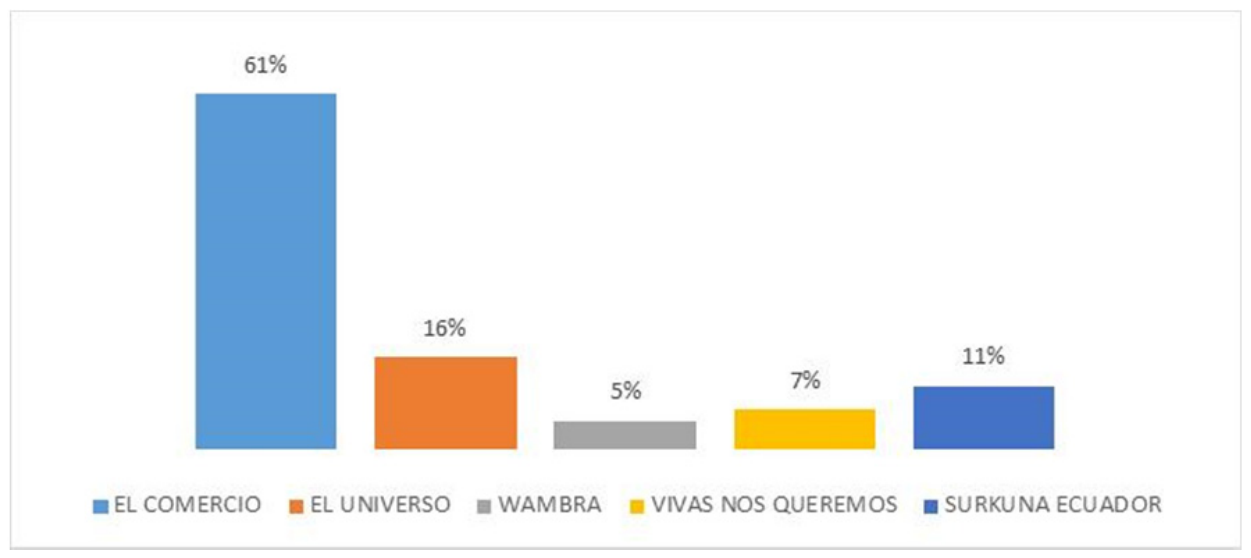

Table 2. Publication on the Martha and Diana cases.

\subsection{Qualitative Results}

The testimonies made by the key informants of the investigation, in answers to the questions:

Are cases of gender violence current as you see it in the media?

If they had to support foreigners leaving the country with what happened in Ibarra, would you do it?

When do you read headlines related to cases of femicide or xenophobia that you perceive?

They were the following:

Inf.1 states that "cases of femicides are not new in Ecuador, but have had a stir, because of the chaos, the wave of violence and the theme of social networks that spread very quickly, and that is what people see". In this way, is shown that there have been frequent cases of gender violence in the country. For inf.2 "we have reacted with foreigners who have come, we have unleashed a wave of violence, and we have responded to this violence with more violence", expressing the way of how to react to actions and effects that are not previously analyzed before society. Among other notable opinions. Inf.1 indicates "My dad was robbed and I was robbed, and I am not aware his a foreign". In his oratory, the fear or uncertainty of the person who carried out the criminal act, a person of the Ecuadorian nation or a foreigner is demonstrated.

Inf.3 highlights, "I think these headlines are made to get an audience, because they are sellers. Also, because people like morbidity." The participant expressly agrees that the media exposes and writes information in a manipulative manner before society. Similarly, Inf.4 states "we as a society believe what the media tells us, we are not a society that investigates", for researchers the common citizen only criticizes the facts, without investigating in depth who is to blame, only in dedication to judge.

Accordingly, Inf.5 reveals "I perceive that the news and information are aimed at causing awareness in the reader, among other words, causing a commotion". For researchers, writing or presenting portals mobilizes or encourages citizens not to be aware of a negative event. In this way, negative attitudes towards society as a whole are generated. Finally, Inf.6 says " That a foreigner has stabbed a woman that has nothing to do with the case, there are ethical rules that prevent you and tell you that it shouldn't be done like that." In general, the opinions gathered in the study show that the media give a lot of attention to specific cases in order to capture the attention of citizens, without respecting ethical norms or rules in the drafting and interpretation of events. 


\section{Conclusions and Discussion}

In that sense, the study focuses its attention on gender-based violence, related by action - effect generated by the media. The analytical results in conceptual, legal, descriptive and interpretative frameworks are set out below. In order to explain the origin of this type of communicative practices of dissemination and information. Only in this way will it be possible to understand the complexity of the problem and formulate proposals aimed at eradicating violence against women as such.

The concept of gender began to circulate in the 1970s and was proposed by the North American anthropologist Gayle (1976), who used this category to explain how society constructs the subordination of women. Also, to question the essentialist positions that explained the disadvantages of women from biological determinations and differences. From the postulates of this author it is explained how sexual differences are translated into real inequality and generating asymmetric power relations between men and women.

From there it is affirmed that the masculine domination, described by Bourdieu (1998), where the discrimination towards women and the attacks to their rights do not obey only to the biological characteristics of some and others. Rather, they are the result of socialization processes and the social and cultural constructions of gender identities.

However, looking at reality from a gender perspective does not only mean considering the differences attributed to men and women, but also requires taking into account the variety of forms of interpretation, symbolization and organization of sexual differences in social relations. But, above all, to look at from which conditions (social/cultural) the information to the female human being is transverse into subordinate subject according to Riquer and Castro (2008).

At the legal level, the Constitution of the Republic of Ecuador (2008) recognizes equal rights, duties and opportunities for all persons and establishes that no one may be discriminated against for reasons of gender identity, sex, sexual orientation, among others; at the same time, it provides that all forms of discrimination are sanctioned by the Law according to article 11, Number 2.

The Constitution not only guarantees the rights set out above, but also prohibits advertising that leads to violence, discrimination and sexism (Article 19); it establishes priority attention for victims of domestic and sexual violence (Article 35); it ensures attention for adult women who are the greatest victims of violence. This legal body classifies three manifestations of violence against women or members of the family: physical, psychological and sexual. However, it does not include critical technological violence. Electronic violence that can be spread through messages or social news.

In other words, in the media, gender not only questions the existence of a feminine and masculine essence. It is the social organization of the relations between the sexes and the naturalization of the inequalities established between them. Other uses given to the concept of gender are studied by Estébanez and Vázquez (2013), who find that the dominant tendency has been to make descriptive use of the media. This trend focuses on the binary differences between male-female, male-female; and warns of misinterpretations that have led to equating it with "woman," where the authors suggest that the gender study includes men.

In analyzing descriptive media results, the dominant and influential power of ICTs in today's society must be recognized. But analytical power is required to explain social relations. Explain the power established in the different spheres of social and human doing. According to the testimonies given by the interviewees and the critical analyses of the researchers, the following can be highlighted. The media are always looking for the strategy of distraction. As a primary element of social control is the strategy of distraction. It consists of diverting the public's attention from important problems and changes decided by political and economic elites. Through the technique of the torrent or flood of continuous distractions and insignificant information.

The strategy of distraction possesses political, economic and social interests. Likewise, distraction is indispensable to prevent the public from taking an interest in essential knowledge in the areas of science, economics, psychology, critical sociology. According to the authors of this study, keep the attention of the Ecuadorian citizen distracted, distance the real social problems. There she is captivated by topics of no real importance.

The problems that spread in the social networks, with respect to the cases Diana and Martha, 
lead to the propulsion of socio migratory problems. In this way, problems are created, then solutions are offered. This method is also called by Chomsky, (2017), "problem-reaction-solution". A problem is created, a "situation" foreseen to cause a certain reaction in the public, so that it is the mandator of the measures that one wants to make accept. For example, when the cases of Diana and Martha were presented in the media, the news was written with an ambiguity that promulgated the problem of social immigration. This is how urban violence develops or intensifies, through aggressive protests in the city of Ibarra (2019).

In the same way, the organization of bloody attacks against migrant citizens in Ecuador in order to make the public the plaintiff and executor of security laws and policies to the detriment of security. These problems, with political and economic interest, gave rise to a series of presentations of solutions. It promotes the massive expulsion of all immigrants who are legally or illegally radicalized in the Republic of Ecuador.

These notifications were posted on social networks for an unliterate reader. That is to say, they were news addressed to a non-critical public in writing and reading. For the participating journalists most of the Ecuadorian advertising during the Martha and Diana cases. Discourse, arguments, characters and particularly manipulative intonation were exposed. These contexts, which generate social violence, used terms of emotional contagion.

much more than reflection. Emotional contagion is part of emotional intelligence. It is presented as a basic affective mechanism by which an organism automatically synchronizes its physiological and behavioral states with those of others to promote affective simulation and altruistic behavior (Ruiz, 2015). Making use of the emotional aspect is a classic technique to shortcircuit rational analysis, and finally the critical sense of Ecuadorian citizens. On the other hand, the use of the emotional register allows opening the door to the unconscious to implant or graft ideas, desires, fears and fears, compulsions, or induce aggressive behaviors in society. Currently, the trends of gender equity, gender violence, among others, are emotional triggers that are rapidly propagated by ICTs.

Due to the quantitative and qualitative results, which were verified and analyzed in this research article, researchers can conclude that Ecuadorian social networks keep the public in ignorance and mediocrity. They make the public incapable of understanding the proper use of technologies and the methods used to control them. Today's Ecuadorian society does not have a critical - investigative - culture that allows an interactive change in communication through ICTs, for the search for solutions to problems or burdens that arise, for the dissemination of news that are written intentionally. The media, whose goal is consumerism and connectivism, encourage citizens to modify and alter the correct sense of the situation. The subject immersed in the media receives data and propagates it to feel identified with technology, through the networks that dominate society, causing hatred and loss of solidarity between residents and immigrants living in the Republic of Ecuador. Therefore, it is recommended not to be part of the emerging distractions of ICTs, which lead to deviation, from what really affects society.

\section{References}

Blumer, H. (1969). Symbolic Interactionism. Perspective and Method, Berkeley and Los Angeles. California: University of California Press.

Bourdieu, J. (1998). La dominación masculina. España: Editorial Anagrama.

Chomsky, N. (2017). 10 Estrategias de Manipulación. Revista comunicar, 1-3 Available in: https://www.revistacomunicar.com/pdf/noam-chomsky-la-manipulacion.pdf

Constitución de la Republica de Ecuador (2008), Asamblea Nacional de Ecuador, Quito.

Cuartas, J. (2017). Humanidades digitales, dejarlas ser. Revista Colombiana de Educación, (72), 65-78. URL: http://www.scielo.org.co/pdf/rcde/n72/n72a03.pdf

Ebrahim, N., \& Atteraya, M. (2019). Women's Household Decision-Making and Intimate Partner Violence in Ethiopia. Academic Journal of Interdisciplinary Studies, 8(2), 284 . Retrieved from https://www.mcser.org/journal/index.php/ajis/article/view/10481/10110

Estébanez; I \& Vázquez; N. (2013). La desigualdad de género y el sexismo en las redes sociales. Colección de estudios sociológicos Gazteak. Spain: Edita Gobierno Vasco. 
Gladilina, I. (2019). Creative Thinking and Development of Professionalism by Procurement Specialists in the Context of Digitalization. Academic Journal Of Interdisciplinary Studies, 8(2), 219. Retrieved from https://www.mcser.org/journal/index.php/ajis/article/view/10473/10102

Hernández, R. Fernández, C, y Baptista, P. (2017). Metodología de la investigación. México: McGrawHill.

Ledesma, T. y Coya, L. (2012). Herramientas de monitorización y análisis del tráfico en redes de datos. Revista Telem@tica, 11 (2), 46-59. URL: http://revistatelematica.cujae.edu.cu/index.php/tele/article/download/62/61

Management Information (2018 (2018), Ecuador: Cifras digitales, perfil de consumidor y ranking Web. URL: http://blog.formaciongerencial.com/ecuador-cifras-digitales-perfil-de-consumidor-y-ranking-sitios-web/

Mayer, J. D., \& Salovey, P. (1997). What is emotional intelligence? In P. Salovey \& D. J. Sluyter (Eds.), Emotional development and emotional intelligence: Educational implications (pp. 3-34). New York: Harper Collins.

Mendoza, D. (2018). Estrategias de enseñanza y su efectividad en los procesos de aprendizaje en los estudiantes de turismo de la Universidad Iberoamericana de Ecuador. Espacios, 39 (43). 25-39. URL: http://www.revistaespacios.com/a18v39n43/a18v39n43p25.pdf

Mendoza, D., Abrigo, I., Romero, J., Cueva, F. \& Cejas, M. (2019). The formative research of ecuadorian university teaching staff. Problems of education in the 21stcentury, 77(3), 364-378.

Mendoza, D., Gomez, S., and Gomez, J. (2018). The emotional intelligence for the improvement of the teaching competences in the facilitators of the Universidad Iberoamericana del Ecuador. Opción, 34(18); 20182048.

Muñoz Rodríguez, L. (2016). Symbolic Violence and Masculine Domination in the Colombian Cinematographic Discourse. REV. COLOMB. SOC. 39(1), pp.103-122. Available in: http://www.scielo.org.co/pdf/rcs/v39n1/v39n1a06.pdf

Riquer, F. \& Castro, R. (2008). Capítulo I. Una reflexión teórico-metodológica para el análisis de la ENDIREH2006", en Castro, Roberto e Irene (coords.) Violencia de género en las parejas mexicanas. Análisis de resultados de la Encuesta Nacional sobre la Dinámica de las Relaciones en los Hogares 2006. México: Instituto Nacional de las Mujeres - Centro regional de investigaciones multidisciplinarias.

Rubin, G. (1976), "El tráfico de mujeres: notas sobre la 'economía política' del sexo", en Marta Lamas (comp.), El género: la construcción cultural de la diferencia sexual, México: Porrúa/PUEG-UNAM, pp. 35-96.

Ruiz, P. (2015). ¿Qué sabemos sobre el contagio emocional? Definición, evolución, neurobiología y su relación con la psicoterapia. Cuadernos de Neuropsicología / Panamerican Journal of Neuropsychology, 9(3), pp. 15-24.

Rueda, R. (2008). Cibercultura: metáforas, prácticas sociales y colectivos en red. NÓMADAS, 28 (1), 8-20. Available in: http://bibliotecavirtual.clacso.org.ar/ar/libros/colombia/iesco/nomadas/28/01-cibercultura.pdf

Schwarz, O. (2011). Who Moved my Conversation? Instant Messaging, Intertextuality and New Regimes of Intimacy and Truth. Media Culture Society, 33 (1), 71-87. DOI: https://doi.org/10.1177/0163443710385501

Wechsler, D. (1940). Nonintellective factors in general intelligence. Psychological bulletin, 37, 444 - 445.

Yermentaeyeva, A., Aurenova, M., Uaidullakyzy, E., Ayapbergenova, A. y Muldabekova, K. (2013). Social intelligence as a condition for the developmentof communicative competence of the future teachers. Procedia - Social and Behavioral Sciences, 116, 4758 - 4763. DOI: 10.1016/j.sbspro.2014.01.1021 